\title{
Objektív és szubjektív mobilitás - válasz Harcsa Istvánnak
}

\section{Huszár Ákos}

A mobilitás-kutatás magyarországi hagyományához képest valóban kevesebb figyelem irányult a területre az utóbbi bő évtizedben, Harcsa Istvánhoz hasonlóan így én is csak remélni tudom, hogy a következő időszakban megnövekszik a társadalmi mobilitás különböző kérdéseit tárgyaló írások száma. Erre tulajdonképpen most minden esély megvan. Egyrészt, a 2016-os mikrocenzus alap, illetve kiegészítő felvételei révén megvalósult egy olyan adatgyűjtés, amely a KSH korábbi célzott rétegződés, illetve mobilitás-felvételihez hasonló feltételeket kinál a kutatásokhoz. Másrészt, a Népességtudományi Kutatóintézetben zajló, Magyarországon példátlan KOHORSZ '18 vizsgálatnak is komoly hozadéka lehet a területen. Harmadrészt, az MTA Társadalomtudományi Kutatóközpontjában is nagyszabású kutatás indult idén, amely a mobilitás jelenségének különböző vonatkozásait igyekszik körüljárni.

Harcsa István idézi dolgozatom két fő kérdését, a következőkben először az ezekhez kapcsolódó két fő állítást szeretném megismételni, illetve a kritikák tükrében alaposabban körüljárni. Végül pedig a mobilitás-kutatásokhoz kapcsolódó normatív elvárások Harcsa István által felvetett kérdéséhez szólok hozzá.

A szubjektív mobilitás problémájának az előtérbe helyezésével dolgozatom egyfelől azt az állítást implikálja, hogy a foglalkozási mobilitás hagyományos indikátorai mellett érdemes a társadalmi mobilitás egyéb, köztük szubjektív mutatóira

\footnotetext{
${ }^{1}$ A mikrocenzus célkitűzéseiről, az adatfelvétel részleteiről, illetve az eddig megjelent eredményekről itt érhetők el információk: http://www.ksh.hu/mikrocenzus2016/. A KOHORSZ'18 vizsgálat jellemzőihez, illetve első eredményeihez lásd: https:// www.kohorsz18.hu/. Az MTA kutatás célkitüzésiről pedig lásd: https://tk.mta.hu/mobilitas.
} 
is figyelmet fordítani. Ez tulajdonképpen egy elég gyenge állítás, hiszen a hazai, illetve a nemzetközi irodalomban is elég elterjedt a megközelítés alkalmazása (lásd például Róbert 1999; Duru-Bellat - Kieffer 2008; Kelly - Kelly 2009; Kraus - Tan 2015; Merllié 2008), most azonban igyekszem ennek a tétjét élesebben érzékeltetni.

Az intergenerációs mobilitás kutatásának magyarországi hagyománya csaknem kizárólag a foglalkozási mobilitás megközelítésére támaszkodott. Amit tudunk a társadalmi mobilitás elmúlt évtizedekben lezajlott magyarországi foIyamatairól, azt elsősorban olyan munkáknak köszönhetjük, amelyek ezt a megközelítést alkalmazták. Éppen ezért különösen fontosnak tartom ezt a megközelítést. Ahhoz, hogy megtudhassuk, hogy a korábbi időszakokkal összevetve miként változtak meg a 2000-es évek után a magyar társadalom mobilitási jellemzői, ahhoz arra van szükség, hogy meghosszabbítsuk a korábban létrehozott idősorokat (Róbert - Bukodi 2004). Sőt, máig ez kínálja a legkedvezőbb feltételeket a nemzetközi összehasonlításokhoz is (lásd Bukodi et al. 2017, Eurofound 2017, Jackson - Evans 2017).

A társadalmi mobilitás mindazonáltal a legáltalánosabb definíció szerint a társadalmi térben történő mozgás (Bourdieu 2010), vagy Andorka Rudolf meghatározása szerint „társadalmi mobilitásnak nevezzük az egyén, illetve a család társadalmi helyzetének megváltozását” (Andorka 1982: 7). A társadalmi helyzet változásáról, illetve a társadalmi térben történő mozgásról azonban többféle módon számot adhatunk annak függvényében, hogy milyen fogalmat alkotunk, illetve miképpen igyekszünk megragadni az egyének jelenlegi, valamit származási társadalmi pozícióját. Az utóbbi időszakban a foglalkozási rétegződés, illetve az ezt bírálók között zajlott viták is megerősítik, hogy a foglalkozási megközelítések csupán részleges módon tudnak számot adni az egyének társadalmi pozíciójáról, s „a társadalmi mobilitás” egyáltalán nem azonositható a foglalkozási rétegek közötti mozgással. Róbert Péter (1986) korai munkája, melyben a társadalmi mobilitást többdimenziós jelenségként vizsgálja, jól szemlélteti ezt. Az egyének a társadalmi helyzet egyes dimenziói mentén mobilnak mutatkozhatnak, mások szerint viszont egyáltalán nem azok. A társadalom egészére vonatkozóan pedig az eltérő típusú mérések alapján így a társadalmi mobilitás különböző, akár egymásnak ellentmondó folyamatai bontakozhatnak ki.

Érdekes ebben a kontextusban utalni arra, hogy a magyarországi mobilitás-vizsgálatok az 1990-es években, illetve a 2000-es években alapvető kontinuitást regisztráltak a rendszerváltás előtt meginduló mobilitás folyamatokkal. A politikai rendszer, s a társadalmi berendezkedés alapvető változásának, illetve a transzformációs válság sokkhatásának ellenére a foglalkozási mobilitás hagyo- 
mányos indikátorai alapvetően változatlanok maradtak, s nem utaltak arra, hogy mélyreható társadalmi változások történtek a rendszerváltást követően (lásd például Andorka - Bukodi - Harcsa 1994, Róbert 1999; Róbert - Bukodi 2004).

Szintén érdekesek ebből a szempontból az Egyesült Államokban, illetve Nagy-Britanniában jelenleg is zajló viták. Ezekben az országokban az utóbbi időszakban a társadalmi mobilitás problémája éles vitákat váltott ki a szakmán belül, de a szélesebb nyilvánosságban is (lásd Huszár - Záhonyi 2018b). A viták gyújtópontját az képezte, hogy több jövedelemalapú vizsgálat a társadalmi mobilitás csökkenéséről számolt be. Az USA-ban többek között Raj Chetty és kollégái mutatták ki, hogy a fiatalabb korosztályoknak kisebb az esélyük arra, hogy elérjék szüleik jövedelmi színvonalát (Chetty et al. 2014, 2016), Nagy-Britanniában pedig Jo Blanden, illetve kollégái állapították meg a brit kohorszfelvételek alapján, hogy az 1958-as kohorszhoz képest az 1970-ben születettek esetében erősebb az asszociáció a szülők, illetve a gyermekeik jövedelmei között (Blanden et al. 2002; Blanden - Machin 2007). Lényeges, hogy ezeknek a vizsgálatoknak mindegyike jövedelmük alapján jellemzi az egyének jelenlegi, illetve származási pozícióját, a Nagy-Britanniára vonatkozó hagyományos foglalkozási alapú mobilitás-vizsgálatok alapján ugyanis nem mutathatók ki hasonló trendek. Ezek mind a mobilitás abszolút, mind a relatív mérőszámai esetében alapvetően konstans eredményeket mutattak (Bukodi et al. 2015; Goldthorpe 2013, 2016). Jellemző, hogy friss európai összehasonlító vizsgálatuk eredményeit Bukodi és kollégái is a következő módon foglalják össze munkájuk alcímében: „A New Account and an Old Story" (Bukodi et al. 2017).

A foglalkozási, illetve jövedelmi alapú vizsgálatoknak közötti viták részben elméleti, illetve módszertani természetűek: milyen módon ragadhatjuk meg a legadekvátabb módon az egyének jelenlegi, illetve származási társadalmi pozícióját, milyen mérőszámok segítségével adhatunk a legjobban számot a szülők, illetve gyermekeik társadalmi helyzete közötti kapcsolat szorosságáról. Ebben a vitában jó érveik vannak a foglalkozási megközelítést alkalmazók képviselőiknek (lásd Goldthorpe 2013), ehelyütt azonban én azt emelném ki, hogy ezek az eltérő típusú vizsgálatok részben más jelenséget is mérnek, és a társadalmi mobilitás különböző aspektusairól szolgáltathatnak információkat. A jövedelmi alapú mobilitás-vizsgálatok sokkal érzékenyebbek a gazdasági konjunktúrák, illetve a recessziós időszakok váltakozására, ahogy a jövedelmi egyenlőtlenségek változására is. E megközelítések esetében tehát a társadalmi térben történő mozgások regisztrálásakor ezek sokkal nagyobb szerepet kapnak, míg a foglalkozási mobilitás esetében különösen a nagyobb gazdaságszerkezeti változások hatása mutatkozik meg az eredményeken. 
A szubjektív mobilitás mutatói kétségtelenül másodlagos szerepet tölthetnek be a tényadatokon nyugvó kutatásokhoz képest. Már az is vizsgálat tárgyát képezi ugyanis, hogy ezeknek pontosan mi a tartalma, vagyis hogy az egyének milyen dimenziókat mérlegelnek, amikor a saját társadalmi pozíciójukról ítéletet alkotnak. Ezek azonban a többi megközelítés mellett újabb információkkal szolgálhatnak a jelenségről, ami Magyarországra vonatkozóan - ahol jövedelemalapú vizsgálatok még nem készültek, s a foglalkozási mobilitásra vonatkozóan sincsenek friss eredmények - különösen értékes lehet. Megállapíthatjuk többek közt, hogy míg a foglalkozási alapú mobilitás-vizsgálatok nem regisztráltak nagy horderejü változásokat a rendszerváltás utáni időszakban, addig e szubjektív adatok szerint más a helyzet: az 1990-es, illetve a 2000-es évek végén még azok voltak többségben, akik úgy nyilatkoztak, hogy romlott a társadalmi pozíciójuk, a 2010-es évek közepére azonban már a felnőtt népesség nagy része úgy érezte, hogy előrelépett a szüleihez képest.

Mivel a társadalmi mobilitás korábbi vizsgálatai nem utaltak ilyen típusú, illetve mértékű változásokra, ez egy kifejezetten meglepő eredmény. Annak, hogy a vita tárgyát képező (egyik) tanulmány ebben a formában, kizárólag a szubjektív mobilitás változásának a kérdésére koncentrálva készült el, tulajdonképpen ez az egyik legfőbb oka.

Valóban számos jogos kérdés felvethető ugyanis a felhasznált mutatók, illetve adatforrások - a 2016-os mikrocenzus társadalmi rétegződés modulja, valamint az International Social Survey Programme különböző hullámai - öszszehasonlíthatóságával kapcsolatban. Ezért foglalkozik egy külön melléklet e kérdésekkel. A 2016-os mikrocenzus, illetve a hozzá kapcsolódó rétegződés modul egy sok szempontból unikális adatfelvétel. Ennek eredményei szigorú értelemben csupán a hasonlóan nagy mintás és (részben) kötelező cenzusokkal, illetve mikrocenzusokkal vethetők össze. Az ISSP ehhez képest 1000-es mintákkal dolgozik, s a válaszadók részvétele az adatfelvételben önkéntes.

Harcsa István az összehasonlíthatóság problémája kapcsán azt emeli ki, hogy a felhasznált kérdések szövegezése némileg eltér a két adatfelvételben. Az ISSP-ban használt kérdések a „társadalmi helyzetre”-re utaltak, a mikrocenzusban szereplőkben viszont a társadalmi helyzet mellett megjelenik az „életvitel” fogalma is mind a kérdezettek, mind pedig a szüleik társadalmi pozíciójára vonatkozóan. Harcsa értelmezésében így az egyik kérdés a státusra, a másik viszont az életvitelre vonatkozó szubjektív vélekedéseket méri. Ez az eltérés valóban nem szerencsés, s a mikrocenzusban szereplő kérdés részben 
valóban más jelenséget mér. ${ }^{2}$ Nehéz azonban ennek az eltérésnek a jelentőségét felmérni. Nem tudjuk megmondani, hogy milyen mértékben, sőt azt sem, hogy milyen irányban okozhatott ez változásokat az eredményekben. Ha súlyozni kell azonban, úgy vélem, hogy ennek kisebb lehetett a hatása. Nem gondolom, hogy az életvitel fogalma a kérdezési szituációban olyan hangsúlyosan jelent volna meg, ami alapvetően befolyásolná az eredményeket.

Sokkal nagyobb jelentőséget tulajdonítok ezzel szemben a kérdések sorrendjének, illetve a szélesebb kontextusnak, amelyben ezek a két kérdőívben megjelentek. A mikrocenzus esetében a szülők társadalmi helyzetére vonatkozó kérdést kellett először megválaszolni, s ezt követte a saját, jelenlegi pozíció értékelése. A kérdésblokk előtt közvetlenül pedig az apa és az anya iskolai végzettségére, foglalkozására, illetve egyéb munkaerőpiaci jellemzőire vonatkozóan szerepeltek kérdések. A szubjektív blokkhoz tehát a mikrocenzusban úgy érkezett el a válaszadó, hogy előtte a fő társadalmi-gazdasági jellemzők alapján tényszerüen nyilatkozott a szülei társadalmi pozíciójáról. Az ISSP kérdőívében ezzel szemben a jelenlegi pozícióra vonatkozó kérdés megelőzte a szülők társadalmi helyzetének az értékelését. Közvetlenül ezek előtt pedig a jövedelemeloszlás igazságosságára, illetve különböző társadalmi csoportok közötti konfliktusok erősségére vonatkozóan tudakolt a felvétel információkat. Az ISSP-ben tehát a jelenlegi társadalmi pozíció értékelése előtt az utolsó impulzust az jelentette, hogy a válaszadók a jelenlegi társadalmi egyenlőtlenségek mértékén, igazságosságán, illetve ezek esetleges káros következményein merengtek. Megítélésem szerint ezek az eltérések együttesen hozzájárulhattak ahhoz, hogy a válaszadók a mikrocenzusban a szüleik társadalmi pozíciójához képest magasabbra értékeljék a jelenlegi társadalmi helyzetüket, ami a szubjektív társadalmi mobilitás mutatóján is éreztethette a hatását.

Összehasonlíthatósági problémák tehát kétségtelenül vannak, ezért is tartózkodtam attól, hogy az ISSP-ből, illetve a mikrocenzusból nyert adatokat közös táblázatba vagy ábrába szerkesszem, s ezért is törekedtem arra, hogy a szubjektív mobilitásra vonatkozóan kirajzolódó tendenciákat közvetve, ezeket az összehasonlíthatósági problémákat kiszűrve próbáljam valamiképpen igazolni. Erre maguk az ISSP felvételek lehetőséget nyújtanak. Ugyan a tanulmányban használt szubjektív mobilitás mutató csak 1999-re, illetve 2009-re vonatkozóan számolható ki, a jelenlegi társadalmi helyzetre vonatkozó kérdés azonban alapkérdés az ISSP-ben, így erre vonatkozóan egy elég csinos idősor állítható össze. Erre támaszkodva pe-

\footnotetext{
${ }^{2}$ A kérdőiv kialakitása során az ISSP kérdése jelentette a kiindulópontot, ezen azonban a tesztelések során kis mértékben változtattunk. A tesztelések azt mutatták, hogy nagy nehézséget okozott a válaszadóknak az eredeti kérdés megválaszolása, ezen igyekeztünk javítani.
} 
dig, ha a teljes mutató nem is, de az egyik elemének a változása nyomon követhető egészen a mikrocenzus lekérdezésének az évéig, azaz 2016-ig. A következő ábrák a jelenlegi társadalmi pozícióra vonatkozó értékelések változását mutatják egyes országokban (az 1-10-es skála pontszámait kettesével összevontam).

1. ábra: A társadalmi helyzet szubjektiv értékelése az ISSP alapján

Subjective experience of own social position based on data from International Social Survey Programme

Magyarország

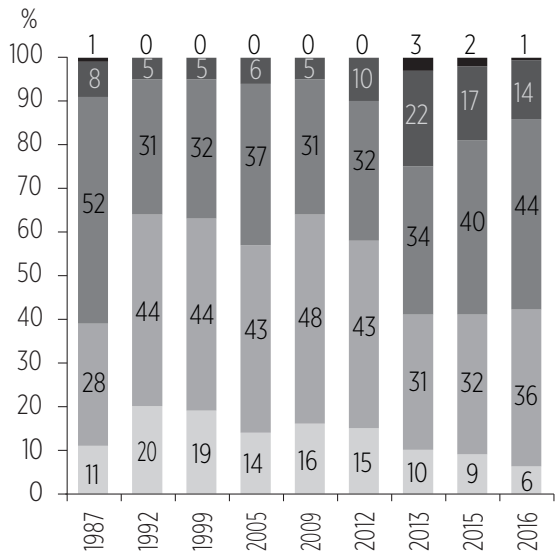

Lengyelország

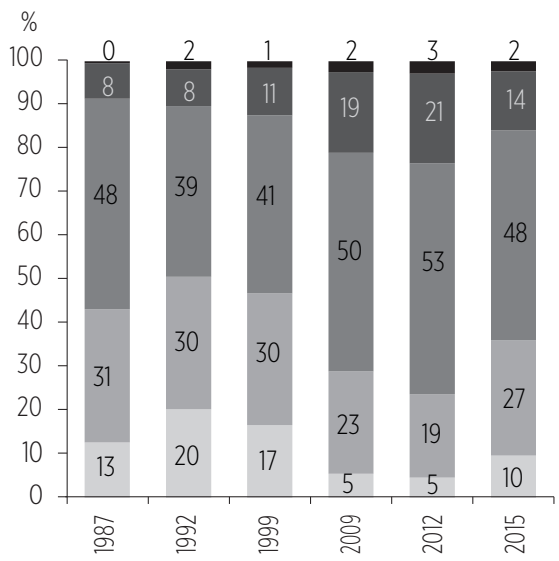

Csehország

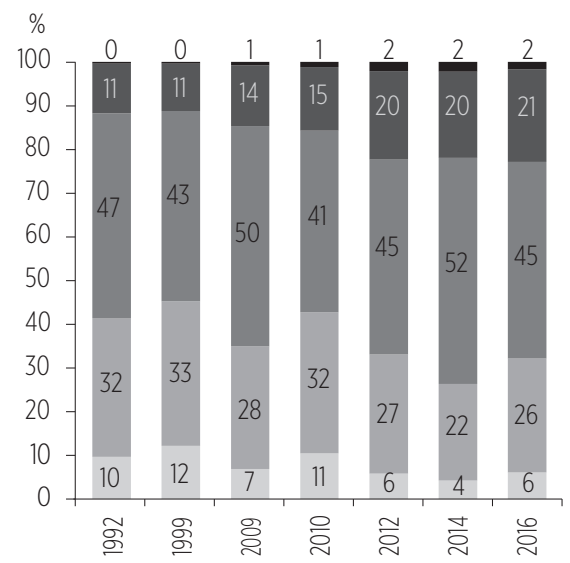

Németország

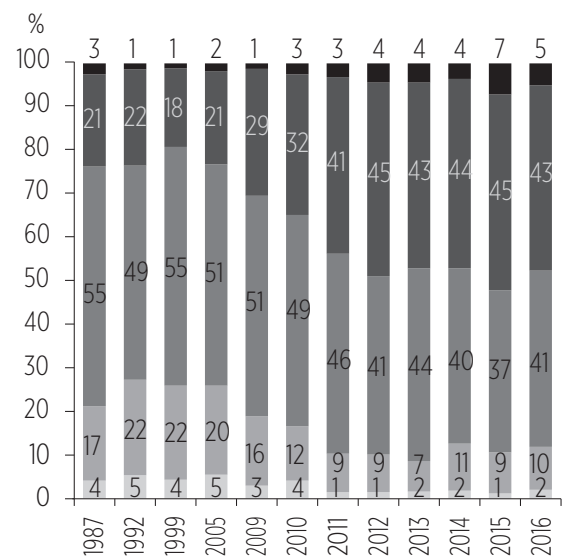
1. alsó
2. alsó-közép
3. közép
4. felső-közép
5. felső

Forrás: ISSP alapján saját szerkesztés 
Ezek az adatsorok a szubjektív mobilitásra vonatkozó eredmények validálásán túl több érdekességgel szolgálhatnak. Közvetlenül a jelen problémánál maradva azonban látható, hogy a 2009-es, illetve a 2012-es eredményekhez képest lényegesen megváltozott a magyar társadalom „,szerkezete” e szubjektív értékelések tükrében. Visszaesett egyfelől azok aránya, akik legalulra, illetve az alsó-közép pozíciójába helyezték magukat, s másfelől, ami talán még látványosabb, erőteljesen növekedett azok aránya, akik úgy ítélték meg, hogy a társadalom csúcsán, illetve a felső-közép pozíciójában vannak. Az 1990 utáni 20 év során e felső két csoport aránya együttesen végig 5\% körül alakult, s a rendszerváltást közvetlenül megelőzően sem érte el a 10\%-ot. A 2010-es években végzett mérések alapján viszont létrejött egy masszív, 15-20\%-os réteg, amely önértelmezése szerint a társadalom legfelsőbb pozícióit foglalja el.

Az ISSP 2010 után végzett felvételei nem tartalmaztak kérdést a szülők társadalmi helyzetéről, tehát közvetlenül nem tudják alátámasztani a szubjektív mobilitás alakulására vonatkozóan megfigyelt trendeket. Ezek az igen nagy arányú változások a jelenlegi társadalmi helyzet értékelése esetében azonban egybevágnak a mikrocenzus alapján jelzett tendenciákkal. Ha a változás pontos mértékének megállapítását a két adatfelvétel közti eltérések nem is teszik lehetővé az nagy biztonsággal kijelenthető, hogy míg az 1990-es, illetve a 2000-es évek végén még azok voltak többségben, akik úgy nyilatkoztak, hogy romlott a társadalmi pozíciójuk, a 2010-es évek közepére azonban már a felnőtt népesség nagy része úgy érezte, hogy előrelépett a szüleihez képest.

Ez egy lényeges eredmény, ami a 2010 utáni társadalmifolyamatok értelmezésében is fontos szerepet játszhat. Ezért is szükséges tovább vizsgálni, hogy milyen tényezők magyarázhatják e szubjektív mutatók által jelzett változásokat.

Végül, Harcsa István felveti a mobilitás-kutatások alapkérdését, hogy mennyire nyitott, vagy zárt a magyar társadalom, s vajon zártabbá vált-e az utóbbi időszakban? Továbbá azt a kérdést is megfogalmazza, hogy vajon milyen várakozásokat, illetve normatív elvárásokat fogalmazhatunk meg a társadalmi mobilitás alakulására vonatkozóan.

Ennek kapcsán fontos rögtön leszögezni, hogy a szubjektív mobilitás mutatója révén mért változások alapján nem következtethetünk arra, hogy a magyar társadalom nyitottabb vagy zártabb lett. Tudjuk, hogy a mobilitás szubjektív érzékelése erősen függ a kortól, illetve attól is, hogy valaki hol helyezkedik el a társadalomszerkezetben (Huszár - Záhonyi 2018a, 2018b). Ha az előbbi ábrára 
pillantunk, akkor azt is megállapíthatjuk, egyáltalán nem csupán magyar jelenség, hogy a 2010-es években a társadalom tagjai nagyobb arányban sorolják magukat a felső társadalmi pozíciókba, vagyis hasonló tendenciák mentek végbe az utóbbi időszakban a régió, illetve Európa több országában. Nem tudjuk azonban, hogy pontosan milyen társadalomszerkezeti átalakulások szolgáltak alapul a mobilitás szubjektív érzékelésének e változásához. E kérdés megválaszolásához valóban csupán a mikrocenzus adatok teljes körü publikálása után juthatunk közelebb. Sőt, egyetértek Harcsa Istvánnal, hogy a statisztikai elemzéseken túl a változások megértéséhez történeti vizsgálatokra van szükség az eltérő történelmi korszakokat bejáró kohorszok miatt. Egyetértek abban is, hogy nem szabad figyelmen kívül hagyni migráció hatását, illetve a tágabb nemzetközi kontextust sem. A vita tárgyát képező dolgozatok csupán előtanulmányok lehetnek az objektív mobilitási folyamatok vizsgálatokhoz, amelyek révén megállapíthatjuk, hogy a szubjektive érzékelt társadalmi mozgásnak, van-e egyáltalán, s ha igen miféle objektív alapja van.

A mobilitás-kutatások normatív háttere szempontjából szintén nagyon érdekesek az utóbbi időszakban elsősorban Nagy-Britanniában, illetve az Egyesült Államokban kibontakozott viták. Ezek ugyanis abba nyújtanak betekintést, hogy mobilitás kérdése miként jelenik meg a szélesebb nyilvánosságban olyan akut társadalmi problémaként, amely egyre inkább politikai, illetve szakpolitikai kezelést igényel. E viták arra ösztökélnek, hogy a mobilitás kérdését ne csupán elvont társadalomelméleti, illetve társadalomszerkezeti problémaként vessük fel, hanem hogy vizsgáljuk egyfelől, hogy milyen társadalompolitikai eszközök lehetnek alkalmasak a probléma kezelésére, illetve másfelől, általánosabban, hogy a társadalmi mobilitás alakulása miként hat, miként hathat a társadalom integrációjára, illetve stabilitására. Fontos tanulság e tekintetben, hogy a foglalkozási mobilitás hagyományos megközelítésének a policy vonatkozásai nagyon korlátozottak, ezek kevéssé alkalmasak konkrét szakpolitika döntések megalapozására.

A mobilitás-kutatások normatív magja e vitákon túl viszonylag jól körülhatárolható, amennyiben ez az esélyegyenlőség elvéhez kapcsolódik, megkülönböztetve az eredmények (vagy feltételek, illetve pozíciók) egyenlőtlenségének a problémájától. Empirikusan az egyenlőtlenségek ez utóbbi fajtáját mindenekelőtt a jövedelmi, illetve vagyoni egyenlőtlenségek különböző mérőszámaival lehet jellemezni (vö. Piketty 2015; Atkinson 2017; Milanovic 2016), a társadalmi mobilitás vizsgálata ezzel szemben azt az ígéretet hordozza, hogy az esélyegyenlőség alakulásáról szolgáltat információkat (Marshall - Swift - Robert 1997). A jövedelmi, illetve vagyoni egyenlőtlenségek társadalmi elfogadottságának az 
egyik alapja maga az amerikai álomba vetett hit, vagyis az, hogy bármekkora távolság is van a társadalom alsó, illetve felső rétegei között, e távolság tehetség, illetve egyéni erőfeszítés révén leküzdhető, s a szegény családba születők számára is adott a lehetőség, hogy a társadalmi létrán felkapaszkodjanak. Az utóbbi években ez a hit kérdőjeleződött meg erőteljesen az Egyesült Államokban, a legújabb mobilitásvizsgálatok ugyanis arra utalnak, hogy a jövedelmi, illetve vagyoni egyenlőtlenségek emelkedésével együtt az esélyek egyenlőtlensége is növekedett. Tulajdonképpen ez a kérdés Magyarországon is. 


\section{IRODALOM}

Andorka Rudolf 1982: A társadalmi mobilitás változásai Magyarországon. Gondolat, Budapest.

Andorka Rudolf - Bukodi Erzsébet - Harcsa István 1994: Társadalmi mobilitás, 1992. In Andorka Rudolf - Kolosi Tamás - Vukovich György (szerk.): Társadalmi riport 1994. TÁRKI, Budapest, 293-310.

Atkinson, Anthony B. 2017: Egyenlötlenség. Mit kellene tennünk. Kossuth, Budapest.

Blanden, Jo - Goodman, Alissa - Gregg, Paul - Machin, Stephen (2002): Changes in intergenerational mobility in Britain. CEEDP, 26. London: Centre for the Economics of Education, London School of Economics and Political Science.

Blanden, Jo - Machin, Stephen 2007: Recent changes in intergenerational mobility in Britain. Sutton Trust, London.

Bourdieu, Pierre 2010: A társadalmi tér és a csoportok keletkezése. In Angelusz Róbert - Éber Márk Áron - Gecser, Ottó (szerk.): Társadalmi rétegződés olvasókönyv. ELTE, Budapest. https://www.tankonyvtar.hu/hu/tartalom/tamop425/0010_2A_19_ Tarsadalmi_retegzodes_olvasokonyv_szerk_Gecser_Otto/ch04s02.html\%23ftn. id539587. Letöltve: 2018. 07. 31.

Bukodi Erzsébet - Goldthorpe, John H. - Waller, Lorraine - Kuha, Jouni 2015: The mobility problem in Britain: new findings from the analysis of birth cohort data. The British Journal of Sociology, 66(1), 93-117.

Bukodi Erzsébet - Paskov, Marii - Nolan, Brian 2017: Intergenerational Class Mobility in Europe: A New Account and an Old Story. INET Oxford Working Papers no. 2017 no. 2017-03.

Chetty, Raj - Hendren, Nathaniel - Kline, Patrick - Saez, Emmanuel - Turner, Nicholas 2014: Is the United States Still a Land of Opportunity? Recent Trends in Intergenerational Mobility. American Economic Review, 104(5), 141-147.

Chetty, Raj - Grusky, David - Hell, Maximilian - Hendren, Nathaniel - Manduca, Robert - Narang, Jimmy 2016: The Fading American Dream: Trends in Absolute Income Mobility Since 1940. NBER Working Paper, No. 22910.

Duru-Bellat, Marie - Kieffer, Annick 2008: Objective/subjective. The two facets of social mobility. Sociologie du travail, (50S), e1-e18.

Eurofound 2017: Social mobility in the EU. Publications Office of the European Union, Luxembourg.

Goldthorpe, John H. 2013: Understanding - and Misunderstanding - Social Mobility in Britain: The Entry of the Economists, the Confusion of Politicians and the Limits of Educational Policy. Journal of Social Policy, 42(3), 431-50.

Goldthorpe, John H. 2016: Social class mobility in modern Britain: changing structure, constant process. Journal of British Academy, 4, 89-111.

Huszár Ákos - Záhonyi Márta 2018a: A szubjektív mobilitás vátozása Magyarországon. Demográfia, 61(1), 5-26.

Huszár Ákos - Záhonyi Márta 2018b: Egyenlőtlenség és társadalmi mobilitás. Esély (megjelenés alatt). 
Jackson, Michelle - Evans, Geoffrey 2017: Rebuilding Walls: Market Transition and Social Mobility in the Post-Socialist Societies of Europe. Sociological Science, 4, 54-79.

Kelly, S. M. C. - Kelly, C. G. E. 2009: Subjective social mobility: data from 30 nations. In Max Haller, Roger Jowell - Tom Smith (ed.): Charting the Globe: The International Social Survey Programme 1984-1989. Routledge, London, chapter 6.

Kraus, Michael W. - Tan, Jacinth J. X. 2015: Americans overestimate social class mobility. Journal of Experimental Social Psychology, 58, 101-111.

Marshall, Gordon - Swift, Adam - Roberts, Stephen 1997: Against the Odds? Social Class and Social Justice in Industrial Societies. Oxford: Clarendon Press.

Merllié, Dominique 2008: How to compare "subjective" and "objective mobility. Sociologie du travail, (50S), e50-e65.

Milanovic, Branko 2016: Global Inequality. A New Approach for the Age of Globalization. Harvard University Press, Cambridge.

Piketty, Thomas 2015: A tőke a 21. században. Kossuth Kiadó, Budapest.

Róbert Péter 1986: Származás és mobilitás. Társadalomtudományi Intézet, Budapest.

Róbert Péter 1999: Társadalmi mobilitás és rendszerváltás. Századvég, 15, 73-86.

Róbert, Péter - Bukodi, Erzsébet 2004: Changes in intergenerational class mobility in Hungary, 1973-2000. In Richard Breen (ed.): Social Mobility in Europe. Oxford University Press, Oxford, 287-315. 